\title{
NAS TRAMAS DAS REDES: \\ MODOS DE SUBJETIVAÇÃO, ITINERÁRIOS URBANOS E SOCIABILIDADE DE TRAVESTIS NA CIDADE DO RIO DE JANEIRO
}

\author{
Monica S. Siqueira ${ }^{1}$
}

\section{Introdução}

Este texto se apoia em trabalho de campo desenvolvido durante pesquisa de doutoramento por um período de quase dez meses alternados entre os meses de setembro a dezembro de 2006 e entre os meses de fevereiro a julho de 2007, e durante os meses de outubro a dezembro do mesmo ano. O universo de pesquisa principal foi composto por nove travestis entre 44 e 68 anos de idade consideradas por elas como "travestis das antigas", residentes na cidade do Rio de Janeiro e que como será tratado em seguida, conformam diferentes redes sociais. Sob a perspectiva da etnografia da duração ${ }^{2}$ (Eckert e Rocha, 2005) realizei um estudo etnográfico de suas narrativas biográficas (Eckert, 19961997; Ricoeur, 1983, 1994, 1997) e formas de sociabilidade (Simmel, 2002). A proposta foi a de compreender os processos pelos quais as travestis, no caso, as "das antigas"3, foram construindo ao longo de suas trajetórias sociais (Bourdieu, 1974; Schutz, 1979) e por intermédio de seus itinerários urbanos, suas interações sociais relacionadas às suas vivências na cidade do Rio de Janeiro.

Por outro lado, minha intenção aqui é desenvolver algumas reflexões que foram brevemente abordadas na tese de doutoramento, especialmente aquelas relacionadas às análises das redes sociais compostas pelas travestis estudadas a partir de suas formas de sociabilidade e seus modos de subjetivação (Foucault, 1982) em particular, os seus 'estilos de travestilidade ${ }^{4}$, ou seja, as formas de 'ser' e/ou 'fazer' travesti em seus cotidianos ao longo de suas trajetórias de vida. Esclareço que os sujeitos pesquisados ao longo de suas

\footnotetext{
${ }^{1}$ Universidade Federal de Santa Catarina, Brasil.

2 Ao buscar realizar uma etnografia da duração e das lacunas da duração e não uma etnografia das lembranças do passado supõe-se que as memórias dos sujeitos estudados não são simples manifestação de um eu profundo, de um passado que se conserva inteiro no decorrer do tempo, mas sim que tais sujeitos, imbuídos em seus "trabalhos de lembrar" o passado, o fazem a partir de suas reflexões e experiências no presente.

3 Este termo é usado, sobretudo para dar conta da experiência de vida de uma geração de travestis e da "sobrevivência" dessas pessoas com relação ao seu "grupo de origem" e em termos da sociedade de forma ampla.

${ }^{4}$ Segundo Benedetti (2005, p.72) o estilo, para as travestis, é uma personagem que vai sendo construída a cada esforço implementado no processo de transformação do gênero. [...] É o modo como ela quer ser representada (ou representar) para os outros atores sociais com quem convive e para toda a sociedade. A meu ver, o autor, refere-se à questão do estilo em termos mais individuais, não desconsidero esta perspectiva, mas, inspirada nela, penso também em termos de formas distintas de construção e representação da experiência travesti enquanto grupo social e em termos de memória coletiva.
} 
vidas promoveram modificações corporais através do uso de hormônios, da aplicação de silicone, bem como da utilização de nomes femininos, mas que, às vezes, em seu cotidiano e ambiente familiar, fazem uso e são tratadas por seu nome de batismo. Cabe ressaltar que a maior parte delas vive cotidianamente em conformidade com o gênero feminino através do uso de vestimentas, acessórios, corte de cabelo, posturas, gestos, voz, sendo que, algumas delas podem adotar uma aparência "andrógina" mesclando elementos considerados apropriados ao gênero masculino e ao gênero feminino. Ou simplesmente uma aparência considerada apropriada ao gênero masculino. Por fim, saliento que entendo a experiência travesti e/ou da travestilidade como aquela que subverte as normas de gêneros hegemônicas, e, portanto procuro compreender as travestis aqui estudadas a partir dos estudos queer ${ }^{5}$ e dos estudos feministas ${ }^{6}$, especialmente apoiada nas teses formuladas por Judith Butler, que em sua teoria da performatividade, desconstrói a noção do gênero como atributo cultural depositado sobre um receptáculo natural (o corpo ou o sexo). Para a autora, o gênero é sempre uma construção, não pode ser entendido como expressão de uma essência, de uma substância. Ou seja, deve ser visto sempre como uma relação entre sujeitos socialmente construídos, em contextos específicos.

\section{Entrelaçando os fios...}

O conceito de rede social (network) tem uma longa tradição na Antropologia que remonta aos estudos de Radcliffe-Brown (1952), Mitchell (1969), Barnes (1972), Both (1976) entre outros, e como bem coloca Lomnitz (2002:2):

las redes sociales son construcciones abstractas que el investigador define de acuerdo al criterio que le interese; es decir, estas relaciones se determinan por algún criterio subyacente, lo que permite identificar estructuras sociales que generalmente no están formalmente definidas por la sociedad y que de otra manera no serían identificables.

O propósito é o de compreender um núcleo de relações que se cruzam no interior de um dado sistema social (Guimarães, 2004). Por exemplo, Barnes, um pioneiro em

\footnotetext{
${ }^{5}$ Queer pode ser traduzido por estranho, talvez ridículo, excêntrico, raro, extraordinário. Mas a expressão também se constitui na forma pejorativa com que são designados homens e mulheres homossexuais. Este termo, com toda sua carga de estranheza e de deboche, é assumido por uma vertente dos movimentos homossexuais, precisamente, para caracterizar sua perspectiva de oposição e de contestação. Para esse grupo, queer significa colocar-se contra a normalização, venha ela de onde vier. Seu alvo mais imediato de oposição é, certamente, a heteronormatividade compulsória da sociedade. Mas, não escaparia de sua crítica a normalização e a estabilidade propostas pela política de identidade do movimento homossexual dominante. Queer representa a diferença que não quer ser assimilada ou tolerada e, portanto, sua forma de ação é muito mais transgressiva e perturbadora (Louro, 2001: 541).

${ }^{6}$ A respeito dos estudos feministas ver, por exemplo: Beauvoir (2009), Scott (2002), Rosaldo (1995), Ortner (1979), Lauretis (1994) entre outros.
} 
utilizar analiticamente a ideia de rede social em seus trabalhos, em linhas gerais, a define da seguinte forma: "Cada pessoa está, por assim dizer, em contato com um número de pessoas, algumas das quais estão diretamente em contato com cada uma das outras e algumas das quais não estão... Acho conveniente falar de um campo social deste tipo como uma 'rede' (Barnes, 1954 apud Both, 1976:107)

Por sua vez, Harnnez (1986:188), ao se questionar sobre a adoção e a utilidade da análise de rede entre os antropólogos, chama atenção para o fato de que, apesar de não ser possível tomar as análises de rede apenas como um instrumento de investigação urbana, esta tende, por outro lado, a se desenvolver com maior importância neste ambiente devido há um maior interesse da antropologia ${ }^{7}$ pela vida urbana e as sociedades complexas (Velho, 1999a).

Em minha tese de doutoramento lancei mão desta ferramenta, sobretudo como descrição etnográfica, ou seja, para dar conta da configuração da trajetória de minha experiência etnográfica, em termos do desenrolar do trabalho de campo no âmbito do 'universo travesti', desde o mestrado até a pesquisa de doutoramento. Desse modo, me baseei principalmente, nos modelos de redes construídos e utilizados por Foote White em seu célebre trabalho Sociedade de Esquina (2005), criado a fim de representar as estruturas dos grupos com os quais trabalhou a natureza das relações e das ações desenvolvidas pelos membros das redes e a estrutura das organizações que faziam parte dos sujeitos de sua pesquisa. Assim, construí quatro diagramas com o intuito de demonstrar as redes sociais pesquisadas durante a pesquisa de mestrado e durante as distintas fases do doutorado (apresentadas em seguida), tendo como base a ideia de rede egocêntrica ou pessoal e de rede parcial (Mitchel, 1969; Harnnez, 1986).

Harnnez (1986) tendo como referência as teses de Mitchell (1969) sobre o conceito de rede social e seu uso analítico para o estudo da vida urbana argumenta que se deve entender uma rede 'egocêntrica' ou 'pessoal' quando está ancorada em algum ponto particular da estrutura das relações sociais, como por exemplo, em um indivíduo ou em ambas as partes de uma díade particular, e passar a um ponto exterior quantas vezes pareçam necessário. Já a possibilidade do uso da 'rede parcial' consiste na construção de uma rede em torno a algum tipo particular de conteúdo de relações e, desse modo, por exemplo, abstrair a 'rede política' da 'rede total'. Este princípio de abstração conduz ao que se costume chamar de rede parcial. Ou ainda, pode-se delimitar uma rede parcial desde o

\footnotetext{
${ }^{7}$ Para uma revisão teórica sobre o uso do conceito de redes sociais na antropologia sugiro também Both, 1976.
} 
ponto de partida de algum ego particular (Harnnez, 1986, p. 187), o que procurei realizar na tese a partir de algumas interlocutoras ao mapear, por exemplo, seus vínculos com vizinhos.

Todavia aqui neste texto o foco de minhas análises recaiu sobre as redes sociais etnográficas construídas no desenrolar do trabalho de campo para o doutorado. Neste sentido, as interlocutoras foram 'classificadas' a partir de duas categorias: "interlocutoras principais" e "interlocutoras ocasionais" (aquelas que durante determinados momentos do trabalho de campo aceitaram participar da pesquisa, mas depois declinaram, e aquelas que participam de forma esporádica).

Ao longo do trabalho de campo ${ }^{8}$ configuraram-se distintas redes de entrevistadas, formadas, por sua vez, por distintas redes sociais (pessoais) de travestis. Contudo, a "rede etnográfica" principal composta por nove sujeitos foi formada a partir de Laura (68 anos) e Camille (64 anos). Assim, de forma arbitrária, trabalhei, para fins de análise, com a ideia de egocentricidade (Guimarães, 2004) a partir de duas interlocutoras chaves para o desenvolvimento da pesquisa de doutoramento. Desse modo, da rede que tem como ego Laura, destacam-se: Raquel (67 anos) e Paola (44 anos); e da rede que tem como ego Camille (64 anos), destacam-se: Jane (60 anos), Fujika (63 anos), Marlene (64 anos), Sarita(63 anos) e Isa (54 anos). É importante ressaltar que as travestis participantes da pesquisa não apenas se definiam como "das antigas”, mas também, exceto no caso de Raquel e Isa, como “travestis-artistas”. São travestis que atuaram em espetáculos teatrais do tipo revista (gênero muito popular na cidade do Rio de Janeiro desde os meados do século XIX até, aproximadamente, fim da década de 1960) e/ou trabalham no ramo de shows de transformismos cantando e/ou dublando cantoras nacionais e internacionais. Saliento ainda, que são sujeitos que ao longo de suas trajetórias individuais e sociais trabalhavam (e trabalham) no ramo artístico concomitante a outras atividades profissionais, como por exemplo, a de professor, cabeleireiro, maquiador e o funcionalismo público, sendo que algumas delas, em diferentes momentos de suas vidas, também exerceram a prostituição. Atualmente, quatro delas (Laura, Raquel, Fujika e Marlene) estão aposentadas pelas suas atividades no mercado formal e uma (Sarita) como autônoma, quatro ainda estavam 'na ativa' e exerciam suas profissões, três (Camille, Jane e Paola) como cabeleireiras e uma (Isa) dessas se dividia entre atividades de costura quando estava no

\footnotetext{
${ }^{8} \mathrm{O}$ trabalho de campo para o doutorado foi realizado por um período de quase dez meses alternados em três fases. A primeira fase, considerada por mim de caráter mais exploratório, ocorreu entre os meses de setembro de 2006 até meados do mês de dezembro do mesmo ano. Já a segunda fase, ocorreu entre os meses de fevereiro a junho de 2007. E, a última fase, ocorreu durante os meses de outubro a dezembro de 2007.
} 
Brasil e o trabalho em cabarés (fazendo shows) ou trabalhando na prostituição através de anúncios em revistas especializadas quando estava na Europa.

Das nove entrevistadas apenas Camille, Sarita, Jane e Paola eram naturais da cidade do Rio de Janeiro, as outras cinco são naturais de distintos estados brasileiros, concentrados na região nordeste. Das cinco, apenas Laura migrou para a capital carioca ainda na infância junto aos seus pais de descendência árabe. Para as outras, a migração para o Rio de Janeiro, em grande parte, esteve estreitamente vinculada à vivência de suas sexualidades com mais liberdade, portanto longe do sistema panóptico familiar ${ }^{9}$. Cinco (Camille, Jane, Paola, Marlene e Sarita) residem em bairros da Zona Sul carioca, duas (Fujika e Isa) em bairros do subúrbio e duas (Laura e Raquel) na região central da cidade. Cinco (Camille, Laura, Paola, Marlene e Sarita) viviam em situação de co-residência com familiares e/ou amigos, três (Isa, Fujika e Raquel) residiam sozinhas e uma (Jane) mantinha uma união estável e morava com seu cônjuge. Somente uma das componentes tem nível superior completo, refiro-me a Laura formada em História e Filosofia, duas tem nível superior incompleto (Paola e Isa), uma (Sarita) tem formação em contabilidade (nível médio), das restantes, três (Camille, Marlene e Jane) tem o antigo científico completo e uma (Raquel) incompleto.

Com intuito de trazer à tona algumas características gerais das redes, procurei demonstrar as especificidades dos vínculos estabelecidos (ou não) entre as travestis envolvidas nas redes (Mitchell, 1969). Para dar conta dos elos existentes entre elas desenvolvi algumas modalidades, como relações de amizade (estreitas ou frouxas ${ }^{10}$ ) relações de trabalho, relações políticas (refiro-me às ONGs) de vizinhança e, finalmente, busquei ressaltar também "as origens" das configurações das redes, ou seja, dos contatos entre elas, a partir das formas através dos quais elas se conheceram ao longo de suas vidas. Neste caso, alguns universos sociais e territórios de sociabilidades se destacaram, como por exemplo: o universo da prostituição, o universo artístico (teatros, shows, cabarés etc.) e outros territórios de sociabilidade como as praças, parques, ruas, especialmente as localizadas no Centro da cidade.

Cabe considerar outro trabalho que me serviu de inspiração realizado por Myriam Lins de Barros (2001), sobre redes sociais entre idosos residentes no bairro do Méier e

\footnotetext{
${ }^{9}$ Faço uma alusão ao sistema panóptico tal como analisado por Foucault (1987), um sistema que podia contar, às vezes, com a cumplicidade de parentes mais próximos e dos vizinhos.

${ }^{10}$ Aqui lanço mão de categorias cunhadas por Elisabeth Both que também se utiliza do conceito de rede social em seu trabalho "Família e rede social" (1976) onde observou que as famílias em suas relações sociais externas pareciam uma rede, ao invés de um grupo organizado, pois apenas certos indivíduos tinham relações entre si e não com todos. Essa rede possui dois tipos de conexidade, a primeira é a malha estreita, onde há inúmeras relações entre os membros dessa rede enquanto que, a segunda é a malha frouxa quando há raras relações desse tipo.
} 
adjacentes, regiões do subúrbio carioca. Neste caso, a autora procurou compreender como são construídas as redes sociais entre estes idosos e como se movimentam nas redes em função das atividades realizadas e da natureza das relações com os elementos das redes (Lins de Barros, 2001:234). Segundo Heilborn, a análise de rede social é uma ferramenta cara ao estudo das camadas médias urbanas tendo em vista, apoiada em Velho (1985), que nesses segmentos, "em razão de uma maior fragmentação dos papéis sociais e de formas menos unívocas do controle social o sujeito encontra campo para exercer suas escolhas" (2004:76). Já Harnnez (1986:228) observa que devemos pensar a cidade usando uma terminologia cunhada por Claben e Wellnan (1974), como uma "rede de redes", sendo que, uma delas, ou várias, podem formar um modo urbano de viver, e juntas vão constituir a cidade como ordem social. Ao longo de suas vidas, as travestis através de seus processos de construção de subjetividade articulados aos seus itinerários urbanos e formas de sociabilidade nos convida a conhecer justamente um sentido de ser e estar na cidade (Eckert e Rocha, 2005) que podem revelar diferentes formas de "fazer-se travesti".

\section{Rede social Doutorado ( $1^{\mathrm{a}}$ fase do trabalho de campo)}

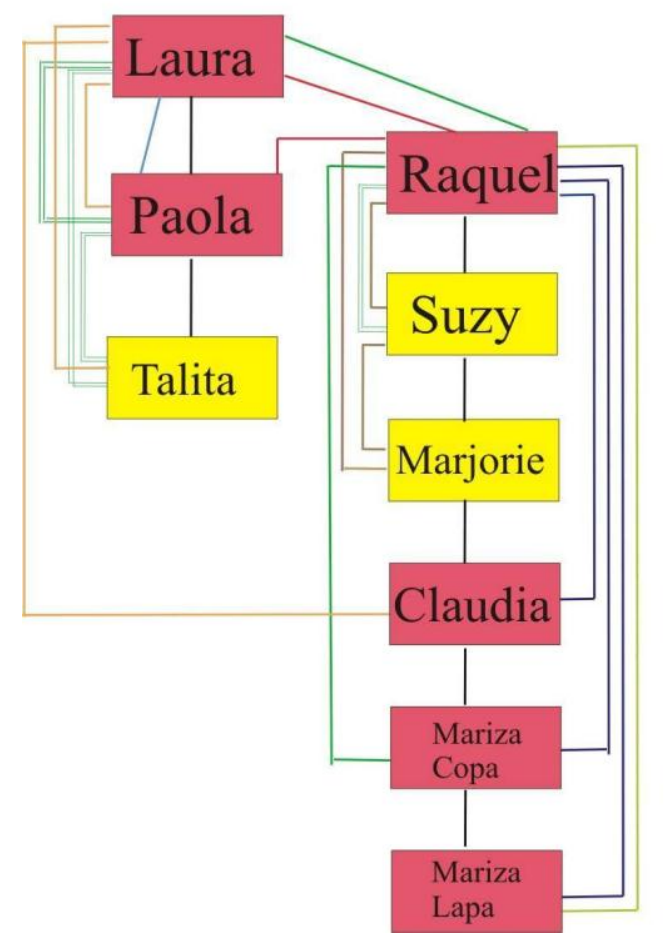

\section{Legendas}

interlocutoras principais

interlocutoras ocasionais

interlocutoras ausentes

Linhas de contato

Relações de conhecimento (como se conheceram)

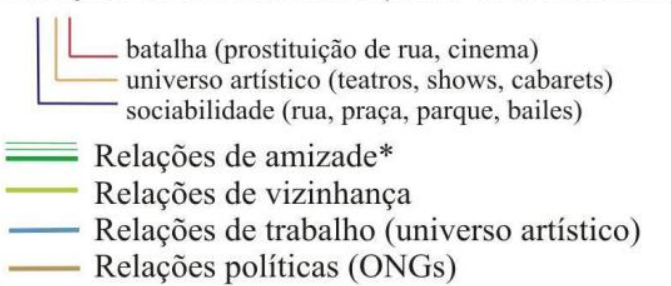

*Relações de amizade $=$ estreitas 


\section{Rede social Doutorado ( $2^{\mathrm{a}}$ fase do trabalho de campo)}

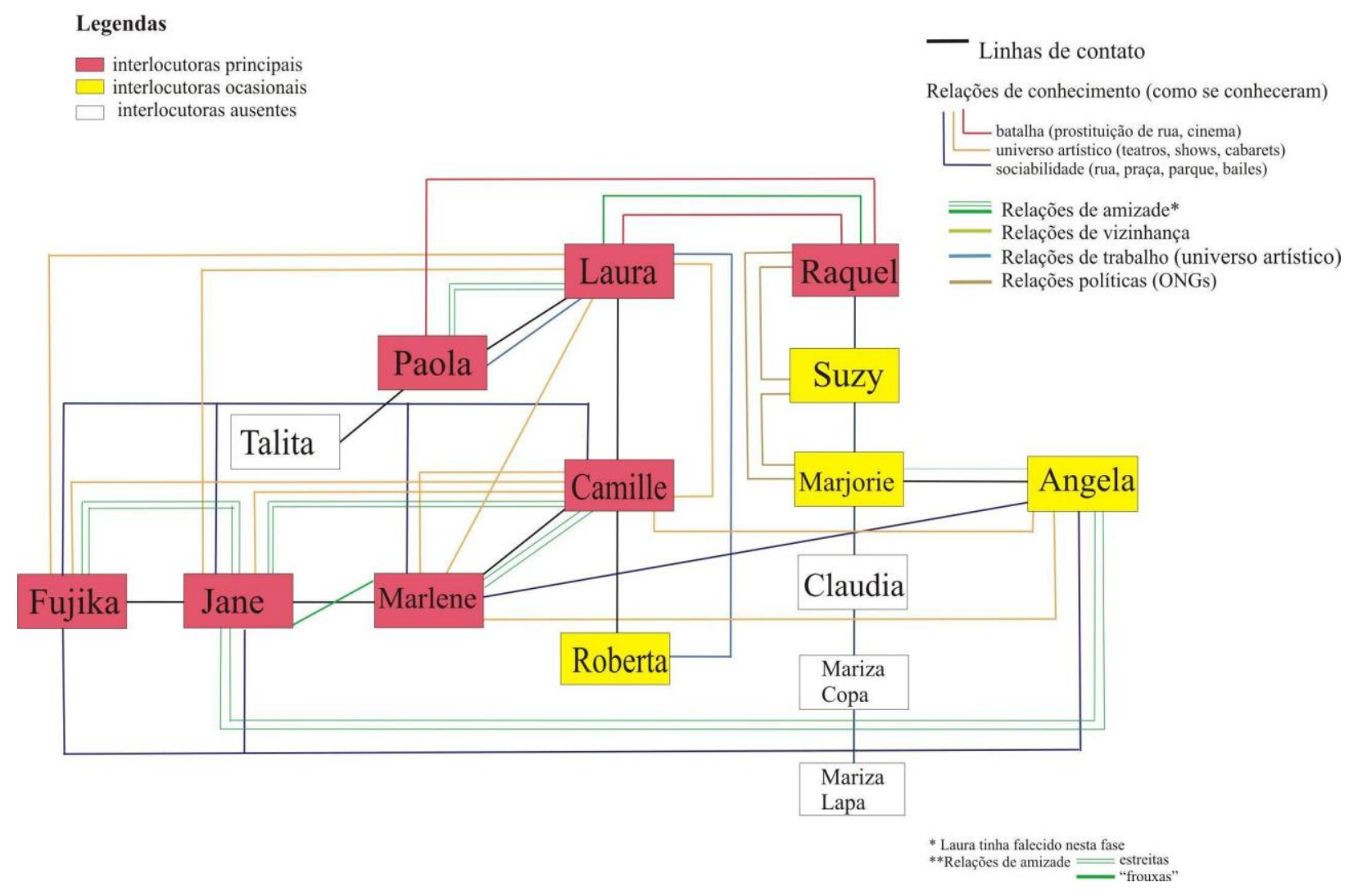




\section{Rede social Doutorado ( $3^{\mathrm{a}}$ fase do trabalho de campo)}

Legendas

interlocutoras principais

interlocutoras ocasionais

interlocutoras ausentes
— Linhas de contato

Relações de conhecimento (como se conheceram) batalha (prostituição de rua, cinema) sociabilidade (rua, praça, parque, bailes)

$\equiv$ Relações de amizade* Relações de vizinhança

_ Relações de trabalho (universo artístico) — Relações políticas (ONGs)

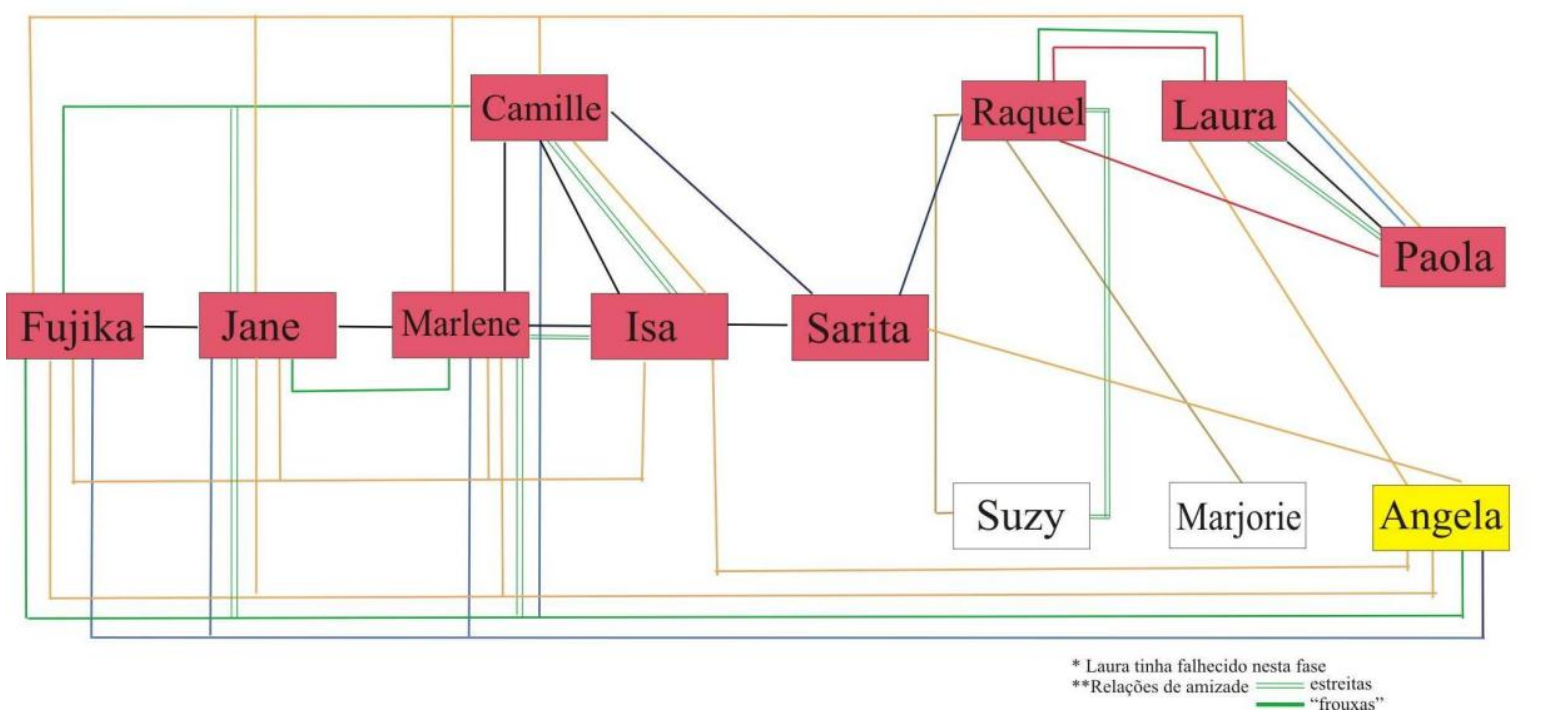

\section{'Tornando-se' uma travesti: redes e pertencimento}

As etnografias sobre travestis (Benedetti, 2005; Kulick, 2008; Pelúcio, 2007, 2009) argumentam que, em geral, para 'tornar-se' travesti e viver como tal, se faz necessário a entrada numa rede de relações já estabelecidas. Pude constatar tal argumento durante trabalho de campo, a partir de minhas observações e através dos depoimentos das interlocutoras. Em suas narrativas sobre as primeiras experiências em "vestir-se de mulher" ou "fazer travesti" (expressões êmicas), bem como em relação aos processos de transformação corporais à base de intervenções envolvendo particularmente o consumo de hormônios, são unânimes em afirmar a importância fundamental de estar inserida numa rede que as iniciassem e as auxiliassem nos conflituosos, árduos, mas principalmente prazerosos caminhos da transformação em travesti ${ }^{11}$.

\footnotetext{
${ }^{11}$ Apesar de estarmos cientes que o tornar-se travesti se configura num processo continuo e de caráter inacabado, o processo de transformação tem como características algumas etapas iniciais que no fim das contas é traço de experiência bastante comum entre elas e que pode ser visto como uma tradição no grupo. As etapas podem ser divididas em: gayzinho (categoria êmica) momento em que assumiu a orientação sexual, em alguns casos sem o conhecimento dos familiares, principalmente em relação as minhas interlocutoras, a fase do montar-se, quando começam a utilizar vestimentas femininas,
} 
Por sua vez, quero salientar que a importância de estar inserido em uma rede de pares é apontada pelas travestis estudadas, muito antes de se compreenderem como travestis, quando ainda eram "boyzinhos", "bichinhas", ou seja, quando começavam a se dar conta de que sua sexualidade era diferente e tida como desviante e anormal ${ }^{12}$, de acordo com os padrões sociais hegemônicos. Portanto, a sexualidade experimentada ocultamente e sob o imperativo do segredo proporcionou a formação de uma rede de relações sociais "de pares" onde compartilham experiências, formas de sociabilidade, elaboram táticas e saberes (De Certeau, 2008) em suas vivências citadinas e interações cotidianas e, vão se criando e estreitando laços de solidariedade. As redes de amigos ou as chamadas 'turminhas', como elas costumam mencionar, como observou Green, ao tratar do desenvolvimento de uma sociabilidade homossexual em meados da década de 50 na cidade do Rio de Janeiro, são compreendidas como "os edifícios de uma subcultura homossexual" que se desenvolvia na cidade e particularmente "funcionavam como uma família alternativa para os homossexuais enfrentarem a hostilidade social” (Green, 2000:290).

Ao solicitar-lhes que falassem a propósito do processo de constituição de uma imagem e corporalidade feminina ${ }^{13}$ ao longo de suas vidas elas evocam, através de suas narrativas, aspectos da própria trajetória social da travestilidade. Suas recordações esmiúçam as primeiras astúcias para dar cabo à composição de uma "aparência feminina" em articulação com a experiência da travestilidade que se desenvolvia em consonância com o "campo de possibilidades" (Velho, 1999a) da época, negociado e manipulado a partir de suas "artes de fazer" e "artes de saber" (De Certeau, 2008). Uma experiência vivenciada em determinadas redes sociais, itinerários urbanos e territórios de sociabilidade como é possível perceber a partir da fala de Sarita:

\footnotetext{
Nenhuma de nós se atrevia a botar roupa de mulher ou andar na rua vestida de mulher na época da ditadura, na época de 60, a não ser quem já era de zona, quem morava pela Lapa. Não fazia não, andava com os cabelos delas assim, maquiavam o rosto, nós todas passávamos angel face e lapisinho embaixo dos olhos e jogava o cabelinho pro lado.
}

\footnotetext{
maquiagem, mais ainda em momentos esporádicos: de lazer, reuniões entre amigos, ou noturnos. E a fase da transformação (que por si só tem suas etapas) que envolve mudanças corporais definitivas, o uso dos hormônios, colocação do silicone etc. E a quarta etapa quando já se considera travesti. Tais etapas também foram observadas e descritas por Pelúcio (2009)

12 Neste sentido, Parker (2002:67) elucida que: “Ainda em meados do século XX categorias como homossexualidade, heterossexualidade e bissexualidade, tornaram-se fundamentais para a discussão médica e científica sobre a vida sexual e foram plenamente incorporadas à linguagem da lei, do governo e da religião, demarcando um mundo de normalidade e anormalidade - de saúde sexual em oposição à doença, perversão e desvio.

${ }^{13}$ Para maiores informações sobre a construção de 'um corpo' e do 'feminino' entre as travestis ver: Benedetti (2005) Kulick (2008) Pelúcio (2009) e Maluf (2002a).
} 
Vale salientar que Sarita em seu depoimento refere-se, em particular, às travestis que compõem a rede na qual está localizada e que tem como ego a Camille, mas também está demarcando a travestilidade -e seus estilos e projetos- sob o ponto de vista de uma experiência geracional. Assim fala sobre outras travestis da mesma geração, com as quais se identifica e que não fizeram parte da pesquisa, e que fazem parte das redes pessoais de algumas das travestis que compõem a rede formada a partir da Camille ${ }^{14}$ e daquelas com as quais ela e as travestis de sua rede não se identificam.

As travestis utilizam a palavra "montagem" composições do feminino e neste processo lançam mão dos mais variados artifícios. Até o surgimento do hábito entre elas de fazer uso do hormônio, em sua 'produção do feminino' não apenas usavam de maquilagem e determinadas formas de pentear os cabelos, como salienta Sarita, mas também usavam de enchimentos - chamados entre elas de Pirelli - para "fazer quadril", ou seja, para dar contornos arredondados ao quadril. Em geral, entre as interlocutoras, elas ressaltam o uso destes artifícios em situações como o carnaval, para suas montagens, para os espetáculos artísticos ou ainda em reuniões íntimas na casa de amigos. Todavia, existem aquelas que por reivindicarem um "corpo muito feminino"16 salientam nunca terem lançado mão desta prática. Além dos enchimentos, a modelagem das sobrancelhas, cintas para afinar a cintura e perucas eram os recursos utilizados para dar "materialidade" as suas performances femininas.

Neste sentido, Sarita nos fala de uma montagem presente entre elas e que se dava num período específico, no caso, a década de 60 , que era feita para determinados territórios de sociabilidade, em bares como o Alcazar e boates como Alfredão em Copacabana e para o footing no calçadão da praia no mesmo bairro ${ }^{17}$, em seus itinerários no Centro da cidade, para estar entre amigos no bar Amarelinho na Cinelândia, para ir aos cinemas nos arredores da praça. Territórios já parte da memória da cidade em termos de sociabilidade homoerótica (Green, 2000; Figari, 2007; Parker, 2002, Guimarães, 2004).

Nota-se que Sarita, por exemplo, faz uma diferença entre as "bichas femininas"18 de sua rede social, formada por "garotos de família" com tendências femininas que "faziam

\footnotetext{
${ }^{14}$ Refiro-me a travestis que se destacam no universo das travestilidades (e também gay) no Rio de Janeiro, tais como: Rogéria, Eloina, Valéria, entre outras.

${ }^{15}$ Esta expressão é também utilizada por transformistas e drag queens (Vencato, 2002), por exemplo.

${ }^{16}$ A idéia de um corpo (e corporalidade) que apresentava desde a adolescência formas 'naturalmente' femininas é discutida em profundidade no capitulo VI da minha tese de doutorado.

${ }^{17}$ Como também salientado em Green (2000).

${ }^{18}$ Os trabalhos de Silva (1993), Vencato (2002) e Henning (2008), abordam o sistema classificatório e hierárquico presentes entre gays, lésbicas, travestis, transexuais, crossdressing, drag queens e drag kings. E que demarcam as diferenças de cada uma dessas categorias (Vencato, 2003). No caso do meu estudo,
} 
travesti" em bailes carnavalescos nos palcos de teatro da cidade, daquelas "de zona" e que moravam na Lapa, talvez, como Raquel, por exemplo, que nesta época já dava seus primeiros passos na arte do trottoir pelas ruas da Lapa e que não demoraria muito para fazer uso de hormônios em seu processo de transformação em travesti.

É possível dizer que, de certo modo, durante suas juventudes a experiência da travestilidade entre elas as aproximava e até se confundia com a dos praticantes de transformismo e/ou crossdressing (Vencato, 2003). É principalmente à medida que elas começam a ingerir hormônios que as fronteiras entre estes sujeitos trans vão sendo demarcadas. Numa extensão do uso de hormônios, a modelagem definitiva das sobrancelhas, através da retirada dos pêlos com uma pinça de modo a obter o aspecto mais ondulado e fino, também é apontada como fundamental neste processo.

O uso de hormônios "surge" entre elas tomando como referência o conjunto de seus relatos, em torno de meados da década de 60 do século passado. Neste sentido, a influência da rede social aparece como fundamental em seus relatos, como observa Marlene ao ser questionada por mim sobre o momento em que passou a ingerir hormônios na forma de anticonceptivos: "ah, elas todas estavam tomando e eu resolvi tomar também”. Já por volta da década de 80, passam a fazer inscrições corporais a partir da aplicação de silicone industrial, no caso de Raquel e Sarita, e de próteses de silicone, no caso de Isa, Fujika e Jane. Estas inscrições, em algumas partes do corpo, representaram uma mudança crucial em suas vidas, à passagem do "fazer travesti" durante as festividades carnavalescas e no teatro, para "tornar-se travesti” em seus cotidianos.

As travestis constroem seu corpo tendo como horizonte para suas intervenções um corpo feminino que é lido com a minúcia de quem lê um texto dramático, que se deve aprender de memória para atuar em seguida (Fernandez, 2004:162). Este processo de aprendizagem, em geral, se dá ainda na infância e adolescência quando escondidas em seus quartos, desenvolvem suas composições da performance feminina. Os trejeitos, os gestos, as expressões, o olhar, a postura, formas de composição de uma performance minuciosamente estudada, memorizada, sonhada, praticada incessantemente, e criativamente interpretada por elas. Em geral, o processo de transformação do corpo tinha como inspiração os padrões corporais e as performances femininas de algumas mulheres muito especiais: as estrelas da Rádio Nacional e dos filmes de chanchadas brasileiros, as

ouvi algumas vezes a expressão bicha-feminina para designar aquele sujeito que se identifica como homossexual, em termos de orientação sexual, e cuja corporalidade se destaca por 'uma feminilidade natural'. 
famosas vedetes do Teatro de Revista e as atrizes de Hollywood ${ }^{19}$. Assim, elas se referem a um padrão estético-corporal feminino e a determinadas performances de gênero condizentes a um universo feminino das décadas de 50 e 60, referência para o universo travesti "das antigas" e que em nada se parece com os padrões estéticos femininos da atualidade. Sarita, durante uma de nossas conversas, comentava comigo a respeito de uma amiga travesti também "das antigas" que, apesar de ser muito alta, tinha suas "estratégias": "Bicha grande não era muito apreciado na nossa época. Afinal, no Brasil as mulheres eram pequenas e então as bichas pequenas e mais delicadas que faziam sucesso"20.

Assim, se por um lado a experiência travesti é marcada pela ideia de que elas ultrapassam as fronteiras do gênero e do corpo (Maluf, 2002b), por outro, elas tomam como base em suas performances e experiências corporais os padrões sociais de corpo e beleza. Neste sentido, se "das antigas" sonhavam com as formas arredondadas, a cintura fina e as pernas grossas de vedetes como Wilza Carla, por exemplo, as travestis nas últimas décadas têm outros modelos de beleza e corporais como inspirações. Quanto a isso, o relato da Raquel a este respeito é bastante ilustrativo:

Hoje em dia elas estão mais para Gisele Bunchen. Querendo ficar magras, peitão, não estão botando muito silicone no bumbum, tá menos. Não está aquele estilo mulherão de chamar a atenção, como tinha a falecida Joinha, uma mulata que tinha uma cintura fina, aquele peitão, aquele corpão, passava na rua todo mundo via porque chamava a atenção. Então este tipo não tem mais.

Hoje, pondera Raquel, elas não querem mais fazer o estilo "travecão"21, seios volumosos, bundas grandes, pernas grossas, maças do rosto salientes e sim, serem mais cocotinhas, ou seja, mais naturais. Por outro lado, é necessário salientar que o estilo “travecão" tampouco é unânime entre elas. Ao contrário, em geral, ouvi críticas por parte de outras interlocutoras, como Sarita, por exemplo, sobre este estilo:

Por que eu via travesti, as bichas com o peito deste tamanho, com aqueles quadris e bundas enormes, com aquele nariz pequeno, com uma cara enorme. E eu fui vendo minhas amigas que eu tinha veneração. Ih! Quando eu via de longe fazendo strip-tease que elas estavam pensando que estavam abafando. Eu olhava [...]. Meu Deus do céu [...]! Aquilo é uma moringa?

\footnotetext{
${ }^{19}$ Fato também percebido por Green (2000) em estudo já referido anteriormente.

20 Tais referências femininas apontam para determinados padrões de beleza e estética corporal que, como colocou Goldenberg, nos remetem às observações de Gilberto Freyre (1986) "sobre as "encantadoras ancas femininas" que possuíam, na cultura brasileira, significados não apenas estéticos, mas, também, enobrecedores das mulheres portadoras de tais formas. Antes "dignas", "virtuosas" e "dignificantes", como adjetivou Freyre, as protuberâncias do corpo feminino parecem estar gradativamente perdendo o valor em nossa cultura" (Goldenberg, 2005:3).

${ }^{21}$ Pelúcio (2005) entre as travestis que pesquisou percebeu a valorização do "estilo ninfetinha" em suas buscas de uma aparência feminina mais natural.
} 
Pelúcio, por exemplo, relaciona o "estilo travecão" quando Paris era o sonho de ascensão das travestis. Um corpo que tem a marca do exagero das formas femininas e cujo excesso remete à imagem masculina (2005:227-228). No entanto, quero chamar atenção que entre as travestis que pesquisei e que foram para Paris em meados da década de 70 para trabalharem em cabarés fazendo shows ou mesmo no caso de algumas delas que trabalharam fazendo prostituição, ao construírem seus corpos evitavam justamente o exagero preocupadas por um lado, em atingir uma aparência feminina que não as vulgarizasse e por outro, com as repercussões entre os familiares.

O que, por sua vez, coloca como relevante mais uma vez, as diferentes redes sociais e os respectivos estilos de vida e visão de mundo que elas expressam. Portanto, apesar de suas referências corporais do "mundo do lúdico" ser até certo ponto, compartilhadas, faz-se necessário levar em conta o universo de travestilidade em que esses corpos são construídos. A Raquel tem como referência principal o universo da prostituição quando fala do corpo; seu corpo foi construído também para atrair clientes. Não quero dizer com isto, tendo em mente a observação de Kulick (2008) quanto ao cuidado de não reduzir todo o processo de fabricação do corpo ao intuito de atender as demandas de um mercado sexual, que todos os investimentos feitos por Raquel em seu corpo para adequá-lo a imagem feminina que desejava, visava apenas o universo da prostituição, mas sim chamar a atenção para o fato de que todo este investimento foi feito tendo como base principal os padrões corporais e morais vigentes neste universo. Camille, por exemplo, sempre procurou fazer 'a linha manequim', de acordo com a imagem feminina que queria atingir, a de uma mulher de sociedade. Sarita empenhou-se em atingir a aparência feminina de uma mulher sexy, sedutora e sensual, mas sem -os temidos- excessos. $\mathrm{O}$ fato é que, como bem coloca Maluf (1998:6):

É difícil definir um caminho para a transformação. Em geral, essa inscrição de novos signos no corpo começa com a gestualidade, a maneira de andar, de gesticular, de falar. A seguir, há a combinação das roupas com a maquilagem. O que significa também um novo aprendizado.

Um aprendizado longo e cuidadoso realizado no âmbito da rede de sociabilidade da qual fazem parte, que se torna elemento essencial neste processo; afinal, como já assinalado, dificilmente um indivíduo inicia o processo de transformação em travesti se não está inserido em uma rede social trans. Os depoimentos de Camille e Paola são um exemplo: 
A primeira vez que eu me vesti de mulher fui produzida por um cabeleireiro amigo meu, para ir ao baile do República. Depois eu fiquei fazendo, foi divino. Todo mundo adorou. Ai era proibido travesti e ficava polícia na porta do baile do República. As bichas se vestiam lá dentro, ou então, chegavam pronta, mas na hora de sair tinham que tirar a roupa. Eu não; passava batido. Saia normal entrava e ninguém percebia que era travesti, ninguém percebia. E fui melhorando, eu não sabia me montar ele foi me ensinando eu fui aprendendo, tomei muito hormônio feminino. (Camille)

Primeiro truque quem me ensinou foi uma amiga minha que é transformista da antiga, da época da Laura. A primeira coisa foi aprender a botar meia-calça. Ela falava: bote uma calcinha por baixo, duas meias cor da pele, uma meia preta e outra calcinha por cima.Ai você bota o que quiser: uma calça, uma saia, você vai estar pronta para sair. Coloca um sapato muito bonito, sapato é muito importante, a maquilagem. Começou a me ensinar a fazer olho fumê e depois começamos a sair juntas. (Paola)

Através de suas narrativas não são pontuados apenas "os primeiros truques", conselhos e ensinamentos dos mais experientes, mas principalmente, as especificidades da experiência da travestilidade destas pessoas; as relações estreitas com transformistas não apenas em suas primeiras experiências, mas ao longo de suas trajetórias, o que parece ser bastante comum entre aquelas que vivenciam a travestilidade tendo como pano de fundo o universo artístico. É recorrente, entre os depoimentos das travestis, especialmente entre as que se prostituem e em algumas das etnografias já citadas, que as relações entre elas e os transformistas e/ou praticantes de crossdressing são bastante conflitantes, não nego isto, pude verificar a existência de tensões entre elas, mas o que pude perceber entre as minhas interlocutoras foi à existência de relações de amizade que tem origem neste processo de aprendizado e de transmissão de saberes que vem atravessando o tempo.

Ao mesmo tempo, tendo em vista o universo investigado, cabe pontuar que à medida que elas falam sobre seus corpos, o processo de envelhecimento é constantemente sublinhado; na minha dissertação de mestrado enfatizei que era basicamente a partir dos aspectos corporais que elas se dão conta das marcas do envelhecimento em seu rosto, em seu corpo, e que esses sujeitos dão lugar à identidade de velha ${ }^{22}$. Por sua vez, observei que as "travestis-artistas" se sentem duplamente cobradas por seu status na rede que são integrantes e com relação ao universo social travesti em termos mais amplos, afinal são "as famosas", as "estrelas", e que não deixam escapar nada em suas críticas extremamente minuciosas e rígidas. Neste sentido, Antunes \& Viegas (2007:58), ao fazerem uso de Goffman, argumentam que a responsabilidade dos famosos pode exacerbar as falhas que expõem aos outros, visto que o fato de se atuar num jogo de espelhos identitários também pode ter o efeito reverso. Afinal, lembremos que o controle e a vigilância também são como

\footnotetext{
${ }^{22}$ Neste sentido, Motta (2002) salienta: a identidade etária da velhice está marcada pela presença do corpo como definidor do que é ou não velho, e do que é ou não saudável.
} 
fios que tecem as tramas das redes, através das quais se compreende alguns códigos ético morais e padrões de comportamento (Velho, 1999a) que tecem o universo simbólico travesti no contexto metropolitano pesquisado.

Diante disso, numa sociedade como a brasileira, e em termos de sociedades ocidentais, onde o culto ao corpo ${ }^{23}$ é predominante principalmente vivendo numa cidade como o Rio de Janeiro, que traduziria em termos nacionais o desenvolvimento de uma “cultura do corpo" 24 , que segundo Goldenberg \& Ramos (2002) é altamente valorizada nos segmentos das camadas médias urbanas por um corpo sempre jovem e bonito, em "boa forma" 25 leia-se magro, rígido e musculoso. Numa sociedade cuja velhice "permitida" é a "em forma", a tal ponto que o sujeito velho não se reconheça enquanto tal, extremamente disseminada a partir da expressão Terceira Idade. Neste sentido, Debert ao analisar as práticas relacionadas à Terceira Idade coloca que estas têm um papel ativo no que ela identifica como reprivatização da velhice onde o envelhecimento: "É transformado em um problema dos indivíduos que se recusam a adotar formas de consumo e estilos de vida capazes de combater a decadência física e ausência de papéis sociais” (Debert, 1999).

Por sua vez, a consciência de que o corpo já não é mais o mesmo pode ser percebido também a partir dos limites e obstáculos que impõe a experiência da travestilidade em certos aspectos. O grande temor é a incapacidade física, como observou Alves (2004) em sua pesquisa com mulheres idosas de camadas médias residentes no Rio de Janeiro, dançarinas de salão, cujo corpo é construído para a dança, espaço onde, sobretudo, este se mostra ágil e sedutor ${ }^{26}$. Neste sentido a questão do trabalho como artista é fundamental. A capacidade para o trabalho, no sentido de manter-se ativa, tem uma

\footnotetext{
${ }^{23}$ A enorme valorização da aparência corporal inscreve-se num processo em que o corpo físico assume um papel fundamental na exteriorização da subjetividade e na construção das identidades. (Iriart et. al., 2009:775).

${ }^{24}$ Para um aprofundamento com relação à valorização do corpo no Rio de Janeiro e, portanto de suas conseqüências em termos de estilo de vida, visão de mundo e formas de ocupação dos territórios da cidade ver, por exemplo, Goldenberg, 2002.

${ }^{25}$ Goldenberg \& Ramos (2002:114) salienta que "assistimos, no Brasil, especialmente nos grandes centros urbanos, a uma crescente glorificação do corpo, com uma ênfase cada vez maior na exibição pública do que antes era escondido e, aparentemente, mais controlado. No entanto, um olhar mais cuidadoso sobre essa "(re)descoberta" do corpo permite enxergar nela não apenas os indícios de um arrefecimento dos códigos da obscenidade e da decência, mas, antes, os signos de uma nova moralidade, que, sob a aparente libertação física e sexual, prega a conformidade a um determinado padrão estético, convencionalmente chamado de "boa forma".

${ }^{26}$ A autora entende a sedução a partir do conceito de coqueteria de Simmel (1969) como um jogo do que se mostra e do que se esconde. Assim, ao refletir sobre suas informantes observa: Ao entrar nesse jogo, a mulher mais velha encontra-se numa posição de domínio, que tradicionalmente lhe é negada. Este aspecto da sedução está diretamente relacionado com a forma como o corpo velho é pensado em nossa sociedade (Alves, 2004:113). Neste sentido, apoiada na autora é que ressalto as astúcias elaboradas pela Raquel na busca de manter-se sedutora.
} 
relação estreita com a manutenção do prestígio como artista, conquistado ao longo de todos esses anos.

Kulick (2008) ao pensar em termos de uma "cultura travesti" argumenta que esta se caracteriza principalmente por valorizar intensamente a juventude e a aparência física, uma cultura baseada na atração, no sex appeal e na feminilidade. A referência de Kulick é basicamente o universo da travestilidade sob a ótica da prostituição, onde o corpo sempre jovem e atraente é condição para manter-se "na batalha". Um universo onde a velhice, por exemplo, pode ser vivenciada por uma travesti por volta dos seus 30 anos como bem observou Silva (1993) e que, por sua vez, coloca em cena outros elementos para se pensar o envelhecimento entre elas e que não é meu objetivo aqui discutir. De todos os modos, algumas dimensões colocadas por Kulick são em geral muito valorizadas pelas travestis que pesquisei ao longo de minha trajetória de pesquisa neste universo. Ser ainda atraente, ter sex appeal e manter-se feminina (considerando que para algumas a feminilidade é medida ao adquirir o status de senhora em seus itinerários cotidianos) é fundamental entre elas e são aspectos utilizados em suas negociações com o processo de envelhecimento e em suas táticas ao reinventarem suas vidas cotidianamente.

Por fim, em seus processos de transformação de "rapazes" a "divas e/ou deusas", em suas primeiras experiências com a travestilidade, "ser travesti" não pode ser entendido com os mesmos contornos que esta experiência ganhou nas últimas décadas. Como ressaltei durante boa parte de sua juventude esta experiência as aproximava de fenômenos como transformismo e ou crossdressing. E, neste sentido, como vimos, o uso de hormônios femininos foi fundamental para o processo de "tornar-se" travesti. Sendo que, a experiência da travestilidade se desenvolve em articulação constante com as redes sociais trans de pertencimento que devem ser entendidas também como "campo de possibilidades" para o desenvolvimento da travestilidade enquanto projeto individual e social (Velho, 1999a, 1999b).

\section{Sociabilidades: as relações com "o meio"}

À medida que minha convivência com as travestis se estreitava ia me dando conta que se destacava entre elas a existência de uma sociabilidade de caráter mais intimista e "qualificada" (Velho, 2002) e que conforme a rede social das interlocutoras, esta poderia se destacar por ser uma sociabilidade intrageracional ou basear-se em interações 
intergeracionais $^{27}$. Neste sentido, intenciono refletir sobre a questão do exercício da sociabilidade entre elas tendo como referência as relações de amizade $^{28}$ e seus estilos de vida.

As travestis estudadas quando falam de suas relações de amizades partem da dicotomia entre "colegas", aqueles com os quais mantêm relações esporádicas e compartilham alguns momentos de sociabilidade pública, e "amigos", aqueles "verdadeiros", que se pode "confiar", com quem se compartilha segredos e a vida privada. Partem também da dicotomia entre os que são "do meio" e os que são "de fora". Os "do meio" é importante salientar que não estão se referindo apenas a travestis, mas também alguns amigos gays que são transformistas. Englobaria a categoria os "de fora" homens e mulheres (em sua maioria) heterossexuais. Durante o campo apesar de ter tido a oportunidade de conhecer alguns desses amigos "de fora” e portando suas redes pessoais para além do "universo" trans (Benedetti, 2005) em momentos de observação participante em seus trabalhos e/ou durante suas apresentações no espetáculo Estrelas $^{29}$ ou ainda ao compartilhar da vida doméstica da Raquel e da Laura, foi, sobretudo com os "do meio" que pude compartilhar de seus momentos de sociabilidade. É necessário pontuar que com relação aos amigos "de fora” apenas no caso da Raquel que essas relações de amizades, no caso as "mais verdadeiras", se confundem com as de vizinhança, ou seja, Raquel, por exemplo, ao refletir sobre sua rede de sociabilidade sempre enfatizou que considerava seus “amigos verdadeiros" um casal de idosos aposentados que eram seus vizinhos. Ao mesmo tempo para se refletir sobre a configuração das redes de sociabilidade no âmbito do universo travesti torna-se fundamental levar em conta suas representações sobre "o meio", como elas costumam dizer. Neste sentido, o depoimento de Sarita é bastante elucidativo:

O mundo nosso é muito difícil, a gente, tem pessoas que estiveram mais tempo assim. Uma na casa da outra, eu recebi muitas na minha casa, vivi com muitas, convivi com todas, falo com todas, mas eu sempre fui um pouco reservado naquilo que se chama amizade. Amizade é coisa que é muito difícil. Você tem colegas, não tem amigos. Eu já com Marquesa, Rogéria, Valeria, muitas operadas que estavam morando fora do país, essas criaturas são meus amigos até hoje, a gente pergunta uma da outra, mais eu não

\footnotetext{
${ }^{27}$ Motta (2004:118) destaca a importância da sociabilidade intergeracional com relação à sociabilidade de idosos. Para a autora, a sociabilidade entre gerações se constitui no fundamento possível de pertença social dos mais velhos. A convivência solidária não deixa espaços para a solidão e a marginalidade.

${ }^{28}$ Tendo como referência os estudos sobre amizade de Allan, 1989; Paine, 1974; Suttles, 1970, Resende (2001) observa que: "Na escassa literatura nas ciências sociais sobre o tema, a amizade é vista em geral como uma relação afetiva e voluntária, que envolve práticas de sociabilidade, trocas íntimas e ajuda mútua, e necessita de algum grau de equivalência ou igualdade entre amigos”. Neste sentido, Velho (1989) coloca que nas sociedades complexas os amigos ocupam um lugar equivalente aos familiares em termos afetivos. A diferença é que há a possibilidade de escolha das redes de amizades.

${ }^{29}$ Nome inventado por mim.
} 
tenho convivência porque uma mora na Suíça, outra na França e eu não tive mais muito contato de viver.

Quero pontuar que se por um lado elas constroem uma imagem do universo trans baseada em intrigas, fofocas, conflitos, falsas relações de amizade e extremamente competitivo, elas também fazem questão de demarcar que existia "um tempo" em que tudo era diferente e que as relações eram baseadas em amizades sinceras e solidariedade, como é possível perceber através da narrativa de Isa:

\begin{abstract}
O CasaNova era ótimo, no tempo de Benito era maravilhoso, todo mundo entrava, todo mundo se divertia, a gente fazia show, era ótimo o CasaNova. Eu adorava, primeiro eu fazia o Rival, depois ia para o CasaNova. Eu, Marlene, fazíamos aquela turmazinha e ia para o CasaNova. Era ótimo, eu gostava naquela época. Agora não, é tudo na falsidade, cada uma querendo matar a outra, puxando o tapete da outra. Não tinha esse veneno todo, tá entendendo? Não tinha essa quantidade de travesti, não tinham tantas e as que tinham, uma considerava a outra, não era assim uma querendo matar à outra, horrível.
\end{abstract}

A idéia romântica a respeito das amizades dos 'tempos de outrora' se articula com a leitura que fazem da experiência da travestilidade de suas juventudes em contraste com a atualidade. $\mathrm{Na}$ "travestilidade das antigas" tudo era melhor e mais legitimo, sobressaia o glamour, existia o talento artístico, ganhava mais dinheiro "na batalha". Hoje vivenciam a banalidade, a vulgaridade e a marginalidade. $\mathrm{O}$ fato é que para elas as relações desse "tempo" praticamente não existem mais, salvo em alguns casos, como os de Camille e Marlene por exemplo.

Desse modo, tomando como referência a rede social que tem como ego a Laura, por onde iniciei minha aventura antropológica para o doutoramento, procurei assinalar com quais travestis que fui conhecendo através de seus contatos, ela mantêm vínculos de amizade e qual a natureza destes vínculos, se mais estreitos ou frouxos, inspirando-me no trabalho de Both (1976). Assim se evidencia entre Laura (68 anos), Paola (44 anos) e Talita (43 anos) a existência de relações mais estreitas de amizades, no sentido de laços sociais mais íntimos e de uma maior convivência cotidiana e de práticas de sociabilidade, tais como lazer (Magnani, 1984), por exemplo. O contexto privilegiado para o exercício da sociabilidade entre elas era o do trabalho no âmbito do universo artístico. Isto não se explica apenas porque Laura e Paola eram 'travestis-artistas' e trabalhavam juntas fazendo shows em uma sauna localizada no bairro do Catete, e aos sábados em uma casa noturna num bairro da Zona Oeste da cidade, cujo público majoritário é formado por travestis (apesar de ter verificado a presença de travestis mais velhas no local, o público travesti é, em sua maioria, composto por sujeitos jovens) gays praticantes do crossdressing e homens das camadas populares, mas principalmente, porque existia entre elas uma relação de 
amadrinhamento (Pelúcio, 2009), onde Paola era vista por Laura como sua afilhada. Talita, que estava sendo iniciada também através de Laura no mundo artístico, por sua vez, era quem, com seu automóvel, levava Laura para fazer seus shows na boate - às vezes a acompanhava a sauna também - citada e para suas apresentações no teatro quando esteve em cartaz com a peça Dei a Elza $a^{30}$ em você encenada no Teatro Posto 5 em Copacabana. Laura considerava-se "tia-avó" das travestis a quem procurava aconselhar e transmitir sua experiência "sem passar sermões" e, em muitos casos, ajudar financeiramente oferecendo trabalho em sua casa ou chamando para fazer shows. Estas relações intergeracionais envolvem a transmissão de uma tradição constituinte do universo das travestilidades no qual as "travestis das antigas", são entendidas aqui como guardiães da memória de seu grupo mais amplo.

Raquel também mantinha relações de amizade mais estreitas com travestis bem mais jovens que ela, de quem recebia visitas em sua casa com certa freqüência, ou saia para almoçar, ou às vezes, para ir a Lapa à noite. Dentre suas relações, destacava-se sua amizade com Suzy, uma travesti negra de 35 anos, residente na Zona Oeste da cidade. Raquel e Suzy se conheceram quando participaram juntas em 2006 de um projeto social voltada para a inserção de travestis e transexuais no mercado de trabalho formal. Desde então mantinham uma relação de muita proximidade e de intensa convivência cotidiana, tal convivência tornou-se ainda mais expressiva quando as duas passaram a trabalhar no mesmo local. Ora Suzy dormia alguns dias da semana em sua casa, ora passava os fins de semana. Por sua vez, a amizade entre elas era indiscutivelmente baseada no conflito (Simmel, 1987, 2002) entre o "amor e o ódio", entre "os desentendimentos e os entendimentos" elas construíam as bases de suas interações. As motivações eram em geral relacionadas à conduta e aos comportamentos da Suzy, alguns deles considerados inapropriados pela Raquel ou simplesmente, devido a pequenas desavenças domésticas próprias da intensa convivência cotidiana que se dava entre elas. Todavia, lembremos mais uma vez com Simmel, o caráter positivo do conflito como aquilo que a primeira vista pode parecer desassociação, é na verdade uma de suas formas elementares de socialização. Ou seja, "a experiência cotidiana mostra quão facilmente um conflito entre dois indivíduos transforma cada um deles, não apenas em sua relação um com o outro, mas também consigo mesmo" (Simmel, 1987:151).

\footnotetext{
${ }^{30}$ A expressão 'dar a Elza' em linguagem êmica e que vem do bajubá significa realizar algum tipo de roubo.
} 
Enquanto assistíamos ao programa de calouros do Raul Gil (o mesmo programa que a Marlene assiste), Suzy comenta comigo que não esta se sentindo muito bem. Está resfriada por isso achou melhor passar o final de semana na Raquel, assim fica mais sossegada e pode descansar. Normalmente aos sábados ela costuma freqüentar um forró que é realizado em seu bairro. Enquanto víamos o programa elas alternavam comentários aprovando ou reprovando os calouros. Em um dos comerciais, Raquel lembra Suzy que ela ainda tem que comprar a mussarela para a lasanha que faria mais tarde para o jantar. (...) Durante o jantar rimos muito com as estórias de Suzy e seus namorados no bairro, especialmente um caso que ela tem super antigo com quem tem uma relação complicada, já que o rapaz é casado. Enquanto conta suas aventuras amorosas, Raquel entre sorrisos, a chama de maluca. Ao recolhermos os pratos da mesa, Raquel comenta que comprou no camelô dois DVDs de lançamento e me fala para depois do jantar escolher um para que possamos assistir. (diário de campo, 15/12/2007)

E como é possível perceber através de um trecho do meu diário de campo uma das características do relacionamento entre elas era a ajuda mútua, a troca continua de favores. Já com relação a "rede das famosas", e que tem como ego a Camille, é normalmente com os amigos/as de longa data, em grande parte, travestis e gays, pessoas que conheceram ainda na juventude e na vida adulta, que a maior parte das interlocutoras vivenciam momentos de sociabilidade como aqueles voltados para o lazer. E neste sentido predomina as reuniões íntimas, onde se reúne um grupo seleto de amigos e que podem se configurar em jantares de aniversários ou para receber alguma amiga travesti que chega da Europa, ou de algum outro estado brasileiro para passar uma temporada na cidade. Almoços em dias de domingo como tive a oportunidade de participar, quando convidada pela Fujika junto com seu amigo Silvio, que é transformista, para comermos seu famoso feijão e passar a tarde conversando e escutando música de cantoras nacionais, em sua maioria as "chamadas cantoras do rádio" e de cantoras internacionais, além de também assistirmos shows em DVDs.

Por sua vez, pude verificar que a rede que tem como ego a Camille, há a presença de um determinado território de sociabilidade bastante compartilhado entre elas. Refiro-me aqui há um clube social que faz parte da 'cena GLS'31 carioca localizado na Lapa e cujo público majoritário era formado por sujeitos homossexuais masculinos de diferentes faixas etárias, em sua maioria, brancos e/ou pardos, pertencentes às camadas médias e médiobaixas. Todavia, apesar da presença de pessoas das mais variadas idades, a frequência se caracteriza pelo seu público composto por pessoas de meia-idade e de idosos, muitos deles transformistas e em menor quantidade de travestis. A maior presença de travestis no clube

31 A sigla GLS quer dizer gays, lésbicas e simpatizantes. Neste sentido, cabe ressaltar que me inspiro em Henning (2008) que, em trabalho já citado, fez uso da expressão cena GLS para referir-se aos contextos espaciais em sentido mais geral, abrangendo tanto bares e boates quanto os demais espaços públicos pesquisados. 
é relativamente recente e é bastante condicionada a determinados eventos, como aniversários ou na ocasião de algum show de transformismo.

$\mathrm{Na}$ época da pesquisa, o clube Alegria $^{32}$ era um dos principais territórios de sociabilidade apropriados por algumas das interlocutoras em seu cotidiano. Sem sombra de dúvida o local é um ponto de encontro para pessoas que se conhecem a muitos anos, em alguns casos desde a juventude. Ali se estabelece uma sociabilidade aparentemente "desprovida de sentido" (Maffesoli, 1984), mas que organiza o grupo em torno de algumas práticas simbólicas relevantes no que concerne a experiência geracional e do compartilhar de memórias (Ricoeur, 2007). Ir ao clube, a meu ver, aponta para múltiplas apropriações e significados na busca pela companhia, não a de qualquer pessoa, mas a dos "amigos verdadeiros", das pessoas de confiança e, principalmente, daqueles com quem se pode trocar experiências e lembranças, como também a oportunidade de conviver com pessoas de outras gerações, de sentir-se em família, sentimento caro para aqueles que estão longe de seus familiares fisicamente ou afetivamente. E da vivencia da travestilidade vinculada diretamente ao acionamento da identidade de artista. Enfim, revela-se como Peixoto (2000) bem observou com relação aos espaços de sociabilidade dos aposentados parisienses e cariocas, um sentimento de identificação com o local que está diretamente relacionado ao pertencimento a uma determinada esfera do seu grupo social mais amplo. Se há um sentimento de identificação por um lado, e uma disputa de memórias por outro, perpassa estes espaços de sociabilidade também um imbricado exercício de duração do qual se aprofunda Bachelard (1988, 1989).

Neste sentido é importante ressaltar que o espetáculo já mencionado e que atuavam juntas durante o campo servia como um elo de (re) união entre elas e proporcionava por sua vez alguns momentos de sociabilidade. Em algumas ocasiões acompanhei mais especificamente Camille e Jane em saídas após este espetáculo, quando se reuniam em algum bar e/ou restaurante nos arredores do Teatro que o espetáculo estava em cartaz, especialmente, quando se apresentaram no Teatro Rival, no Centro, e se reuniam em um barzinho na mesma rua do teatro. E quando se apresentaram no Baden Powel, em Copacabana e se reuniam em um restaurante algumas quadras do local. Apesar de Marlene, Fujika e Ângela ${ }^{33}$ (60 anos) participarem do espetáculo, elas não iam conosco e seguiam

\footnotetext{
${ }^{32}$ Nome fictício.

33 Ângela uma travesti também considerada das antigas que conheci durante o XVI ENTLAIDS (Encontro nacional de Travestis e Transexuais que atuam na luta e prevenção à AIDS) realizado em São Paulo em junho de 2007.
} 
para suas casas. Marlene sob a alegação de cansaço, Fujika e Ângela sob a alegação que moravam longe e que depois de certa hora "ficava muito perigoso voltar para casa".

E se todas se consideram "amigas" estas relações de amizade se configuram a base de gradações, ou seja, para dar um exemplo, Marlene e Camille se consideram "grandes amigas, quase como irmãs" assim sublinham seu "grau" de afinidade em relação às outras travestis da rede social da qual fazem parte. Assim, se todas se consideram amigas - e aqui é fundamental o sentimento de pertencerem a uma mesma geração - os graus de afetividade e as relações de convivência cotidiana se dão de formas diferenciadas. Notamse assim, como no interior das redes algumas relações foram se tornando mais estreitas, e assim, culminando no desenvolvimento de determinadas formas de sociabilidade entre elas.

É necessário ter em conta que as travestis estudadas fazem parte de uma geração ${ }^{34}$ marcada profundamente pelo advento da AIDS. Como nos informa Terto Jr, a AIDS no início dos anos 80, nos EUA, chegou a ser concebida pela ciência como um problema de homossexuais, recebendo o nome de Imunodeficiência relacionada à Homossexualidade (Gay Related imunodeficience - GRID) (Terto Jr, 1996:90). Quando a síndrome ganha visibilidade no Brasil, também nesta época ${ }^{35}$, torna-se conhecida como peste gay ou "peste rosa", numa associação imediata da síndrome com a homossexualidade masculina e como punição por práticas sexuais moralmente reprovadas. De acordo com Pelúcio (2009) em torno da epidemia da AIDS muitos foram os discursos formulados: os médicos, a mídia, a igreja católica, os ativistas dos movimentos sexuais, organismos internacionais ligados a saúde, seriam alguns exemplos, a partir dos quais se configurou um determinado "grupo de risco", num contexto onde junto com os homossexuais, as travestis se tornaram um dos principais “membros" desse "grupo". Tal associação, segundo Terto Jr (1996) e Parker (1994), só agravou os preconceitos e atos discriminatórios e, por conseguinte, fomentou práticas homofóbicas e transfóbicas com relação aos sujeitos homossexuais e travestis.

Em nossas entrevistas e/ou conversas informais, as travestis falavam sobre a AIDS especialmente quando falavam de suas relações de amizade. "Os mais íntimos mesmos, já morreram" me disse uma vez Fujika, referindo-se a pessoas com quem estabeleceu vínculos nos primeiros anos de sua chegada ao Rio de Janeiro e que foram fundamentais

\footnotetext{
${ }^{34}$ O conceito de geração é utilizado aqui conforme a definição dada por Debert (2000:60): “a idéia de geração implica um conjunto de mudanças que impõem singularidades de costumes e comportamentos a determinadas gerações. Daí falar-se da geração do pós-guerra, da televisão, de 68. A geração não se refere às pessoas que compartilham a idade, mas às que vivenciaram determinados eventos que definem trajetórias passadas e futuras".

${ }_{35}$ O primeiro registro oficial de um caso de AIDS no Brasil foi diagnosticado em 1984 na cidade de São Paulo (Pelongher, 1987 apud Pelúcio, 2009:114)
} 
em sua trajetória de vida. "Minhas amigas de verdade morreram com a menina", afirmava com um tom melancólico Raquel, referindo-se a três travestis que conheceu durante a época "da batalha” e com quem mantinha relações muito intimas de amizades. Raquel ao narrar seu tempo de batalha em um famoso cinema do Centro da cidade, destaca que durante a década de 80 e até início dos anos 90, toda semana ela e suas companheiras de trabalho "sentiam falta de uma travesti' e depois descobriam que tinha morrido infectada pelo vírus. Para além dos possíveis exageros de seu comentário, o certo é que a AIDS passou a fazer parte de seus cotidianos, principalmente daquelas que se prostituíam.

Em algumas ocasiões durante as entrevistas, ao folhearmos as Revistas Manchete e Fatos e Fotos em suas edições de cobertura do carnaval carioca, elas apontavam com frequência aquelas que já morreram com a menina, o babadinho, a tia, alguns dos nomes com os quais a síndrome é batizada entre elas. Tal como observou Pelúcio, entre as travestis que estudaram na cidade de São Paulo, notei que a AIDS é um assunto tratado 'quase como um tabu', sobre o qual se comenta em sussurros entre amigos, em segredo, e às vezes como fofoca. Neste sentido, Pelúcio faz uma interessante articulação entre os muitos apelidos que a AIDS é tratada por elas:

Entre as travestis a AIDS pode ser silenciada e até mesmo negada, sendo quase um tema tabu, sobre o qual se calam. Talvez, por isso, entre elas a AIDS tenha recebido nomes carinhosos "tia lili" ou simplesmente "tia" (denotando parentesco, afinidade a alguém mais velho que cuida), babadinho, bichinho, palavras que abrandam, minimizando o peso pelo uso do diminutivo. (Pelúcio, 2009: 189)

Para além destas ocasiões falava-se sobre a AIDS para salientar que não estavam infectadas ou eram portadoras do vírus, demarcando um estilo de vida que prima pelo cuidado de si e afastando-se da travestilidade estigmatizada. Raquel e Isa sempre fizeram questão de pontuar que assim que surgiu a AIDS elas passaram a usar sistematicamente preservativos em suas relações sexuais, não apenas com os clientes, mas com os eventuais maridos, namorados e $\operatorname{casos}^{36}$. O certo é que até hoje elas se cuidam e fazem exames períodos de HIV e, mostravam num misto de orgulho e alívio os resultados negativos. Desse modo, ter 'escapado' da AIDS se configura em capital simbólico fundamental

\footnotetext{
${ }^{36}$ Kulick entre as travestis que pesquisou observa que apenas uma delas de nome Keila (atualmente uma das principais ativistas dos movimentos de travestis) afirmava fazer uso do preservativo em suas relações sexuais sem discriminar os parceiros. Para o autor, as travestis que fazem prostituição vinculam o preservativo com trabalho, isto é a prostituição e por isso os dispensam em suas relações afetivo-sexuais. (Kulick, 2008:46)
} 
quando demarcam fronteiras entre elas. É com orgulho que algumas delas enfatizam que suas doenças são aquelas que todo indivíduo velho/velha tem.

Em linhas gerais, a partir das distintas redes sociais de travestis que fizeram parte da pesquisa, nota-se uma espécie de contração da sociabilidade pública e redução dos laços sociais que contrasta fortemente com a juventude e a idade adulta. Em alguns momentos, a expressão "caseira" é acionada por elas, contemporaneamente, para dar conta do "costume" que adquiriram de "passar mais tempo em casa", delimitando um estilo de vida "mais tranqüilo". Numa clara pontuação a um ciclo de vida, muitas das travestis referem-se a essa restrição de seus deslocamentos como fenômeno decorrente de uma opção individual em suas vidas, agora mais dedicada a um tipo de sociabilidade voltada para esfera do "privado".

Evidencia-se que este movimento de contração da sociabilidade pública está relacionado com o processo de envelhecimento entre elas, inclusive em alguns momentos pude perceber em suas narrativas biográficas uma espécie de "rejeição" a determinadas formas de sociabilidade de outrora, vividas principalmente na juventude: "eu não fico mais à toa na rua" (expressão empregada por Paola). Outro aspecto mencionado por elas e que merece atenção, refere-se às transformações pelas quais a cidade do Rio de Janeiro e alguns de seus bairros vem passando nas últimas décadas. As imagens da violência, do perigo, do medo e da insegurança influenciam, segundo elas, seus deslocamentos e suas formas de ocupação dos espaços públicos que elas vêm realizando, seja em seus bairros de moradia, seja naqueles onde trabalham. A temática da violência urbana (Zaluar, 1996, Soares, 19941995; Eckert, 2002) é matéria de suas representações da cidade no presente em profundo contraste com o Rio "de antigamente", "uma cidade muito mais tranqüila" e "que se podia sair despreocupado pelas ruas". Vale salientar ainda que Lins de Barros (1997, 2006) também verificou em suas pesquisas, com velhos moradores da cidade do Rio de Janeiro, estas representações da cidade envolta em um passado idílico.

À medida que as redes etnográficas iam sendo formadas fui me dando conta que a maior parte das travestis se conhecia da época de suas juventudes, quando compartilhavam determinados espaços da cidade e vivenciam formas de sociabilidade. As idas a Rádio Nacional, os desfiles na Cinelândia e na Praça Paris no Centro, os concursos de Miss Brasil no Maracanãzinho, as "pegações" (expressão êmica para interação sexual ocasional) no Aterro do Flamengo, as festividades carnavalescas, entre outros. Alguns desses territórios de sociabilidade eram também locais de realização do trabalho artístico, como os cabarés da Lapa. Todavia, as densidades das relações variavam muito e em alguns casos os 
contatos e os vínculos entre elas ficava relegado ao passado. Desse modo, as articulações entre as redes senão era de todo inexistente, era bastante esporádica e quando acontecia era em grande parte em decorrência da atividade artística, como por exemplo, nas ocasiões em que Laura era convidada a participar no espetáculo encenado por Camille e sua rede social. Por outro lado, entre aquelas cujos contatos e vínculos eram muito presentes, como especialmente no caso da rede formada a partir de Camille, a vivência da sociabilidade proporcionava o convívio entre amigos de longa data, a troca de experiências, seja as do cotidiano ou aquelas revividas, mas principalmente trocavam impressões sobre a experiência de "envelhecer juntas" (Ricoeur, 2007).

\section{Comentários finais}

Voltar-se para a constituição de suas redes sociais é vislumbrar o complexo processo de constituição de subjetividades das travestis, seus projetos de travestilidade em suas intricadas relações com os espaços citadinos e as formas de sociabilidade que são desenvolvidas. A utilização das redes foi importante para vislumbrar as práticas e territórios de sociabilidade encontrados entre elas e a importância destes para a construção de vínculos e laços sociais, enfim, para o desenvolvimento de redes de sociabilidade entre elas, que ao mesmo tempo, evidencia a composição de diferentes redes e diferentes vínculos no interior das redes que dizem respeito a diversos estilos e projetos de travestilidades e que, por sua vez, expressam processos de negociação de identidades bem como de "memórias em disputas" da travestilidade enquanto fenômeno social. Desse modo, as redes de travestis com as quais trabalhei à medida que foram sendo tecidas por diferentes "formas de ser travesti" colocam "em jogo" diferentes memórias e imagens da travestilidade. Diante disso, sugiro que as redes sociais se constituem em espaços de memória, de circulação e transmissão de saberes, de tradição, enfim, de um "ser e estar junto".

\section{Referências}

ALVES, Andréa Moraes. A dama e o cavalheiro: um estudo antropológico sobre envelhecimento, gênero e sociabilidade. Rio de Janeiro: Editora FGV, 2004.

ALVES, Andréa Moraes. "Mulheres, corpo e performance: a construção de novos sentidos para o envelhecimento entre mulheres de camadas médias urbanas". In: LINS DE BARROS, Myriam Moraes (Org.). Família e Gerações. Rio de Janeiro: Editora FGV, 2006. p.67-89. 
ANTUNES, Gomes Catarina; VIEGAS de Matos Susana. A identidade na velhice. Lisboa: Âmbar, 2007.

ARAN, Márcia; PEIXOTO JUNIOR, Carlos Augusto. "Subversões do desejo: sobre gênero e subjetividade em Judith Butler". In: Cad. Pagu, n. 28, June. Campinas: Unicamp, 2007.

ARANTES NETO, Antonio Augusto. Paisagens Paulistanas: transformações do espaço público. Campinas: Editora da UNICAMP; São Paulo: Impressa Oficial, 2000.

ATTIAS-DONFUT, Claudine. "Sexo e envelhecimento". In: PEIXOTO, Clarice Ehlers (Org). Família e envelhecimento. Rio de Janeiro: FGV, 2004. p.86-108.

BACHELARD, Gaston. A dialética da duração. São Paulo: Ática, 1988.

BACHELARD, Gaston. A poética do espaço. São Paulo: Martins Fontes, 1989

BARNES, J.A. "Networks and political process". In: MITCHELL, C. (org) Social networks in urban situations. Manchester: Univ.Press, 1969. p.51-76.

BEAUVOIR, Simone de. A velhice. Tradução: Maria Helena Franco Monteiro - 2. ed. Rio de Janeiro: Nova Fronteira, 1990.

BEAUVOIR, Simone de. O Segundo sexo: Fatos e Mitos. Tradução Sérgio Milliet 2.ed. Rio de Janeiro: Nova Fronteira, 2009.

BENEDETTI, Marcos Renato. Toda feita: o corpo e o gênero das travestis. Rio de Janeiro: Garamond, 2005.

BENÍTEZ, María Elvira. "Buraco da Lacraia: Interações de raça, classe e gênero". In: VELHO, Gilberto. (Org.). Rio de Janeiro: Cultura, Política e Conflito. Rio de Janeiro: Jorge Zahar Editores, 2007. p. 128-155.

BENTO, Berenice. A reinvenção do corpo: sexualidade e gênero na experiência transexual. Rio de Janeiro: Garamond, 2006.

BERGER, Peter; LUCKMANN, T. A construção social da realidade: tratado de sociologia do conhecimento. 5. ed. Petrópolis: Vozes, 1983.

BOSI, Ecléa. Memória e sociedade: lembrança de velhos. São Paulo: Companhia das Letras, 1994.

BOTH, Elizabeth. Família e rede social. Rio de Janeiro: F. Alves, 1976.

BOURDIEU, Pierre. "Gostos de Classe e Estilos de Vida". In: ORTIZ, Renato: Pierre Bourdieu. São Paulo: Editora Ática, 1983. p.82-121.

BOURDIEU, Pierre. "Condição de Classe e Posição de Classe". In: BOURDIEU, Pierre. A economia das trocas simbólicas. São Paulo: Editora Perspectiva, 1974.

BUTLER, Judith. Problemas de gênero: feminismo e subversão da identidade. Rio de Janeiro: Civilização Brasileira, 2003.

BUTLER, Judith. "Corpos que pesam: sobre os limites discursivos do sexo". In: LOURO, Guacira Lopes (Org.). O corpo educado: pedagogias da sexualidade. Belo Horizonte: Autêntica, 2001, p.151-172.

BUTLER, Judith. Cuerpos que importan: sobre los limites materiales y discursivos del sexo. Buenos Aires: Paidós, 2002.

CABRAL, Benedita E. S. Lima. "A vida começa todo dia". In: Revista Estudos Feministas, v. 5, n.1. Florianópolis: Editora UFSC, 1997. p.159-168.

CARRARA Sérgio e VIANNA, Adrianna. "Tá lá um corpo estendido no chão. A violência letal contra travestis no Município do Rio de Janeiro". In: Physis: Revista de Saúde Coletiva, v.16, n.2. Rio de Janeiro, 2006. p. 233-249.

CEBALLOS, Rodrigo. "Trilhas urbanas, armadilhas humanas. A construção de territórios de prazer e de dor na vivência da homossexualidade masculina no Nordeste brasileiro dos anos 1970 e 1980”. In: RAISSA SCHPUN, Mônica (Org.). Masculinidades. São Paulo: Boitempo Editorial; Santa Cruz do Sul: Edunisc, 2004. p.129-150. 
CSORDAS, Thomas. "Introduction: the body as representation and being-in-the world". In: CSORDAS, Thomas J. (Org.). The Existencial Ground of Culture and Self. Cambridge: Cambridge University Press, 1994.

DEBERT, Guita Grin. A reinvenção da velhice: socialização e processos de reprivatização do envelhecimento. São Paulo: EDUSP/FAPESP, 1999.

DE CERTEAU, Michel. A invenção do cotidiano: 1 artes de fazer. Tradução de Ephraim Ferreira Alves. 15.ed. Petrópolis, Rio de janeiro: Vozes, 2008.

ECKERT, Cornelia. "Questões em torno do uso de relatos e narrativas biográficas na experiência etnográfica". In: Revista Humanas - Revista do Instituto de Filosofia e Ciências Humanas - IFCH, v.16, n.1. Porto Alegre: 1996-1997. p.21-44.

ECKERT, Cornelia. "A cultura do medo e as tensões do viver a cidade: narrativa e trajetórias de velhos moradores de Porto Alegre". In: MINAYO, Maria Cecília de Souza; COIMBRA JR, Carlos E. A. (Org.) Antropologia, Saúde e Envelhecimento. Rio de Janeiro: Editora Fiocruz, 2002. p.73-102.

ECKERT, Cornelia; ROCHA, Ana Luiza Carvalho da. O Tempo e a Cidade. Porto Alegre: Editora da UFRGS, 2005.

ECKERT, Cornelia; ROCHA, Ana Luiza Carvalho da. "Premissas para o estudo da memória coletiva no mundo urbano contemporâneo sob a ótica dos itinerários de grupos urbanos e suas formas de sociabilidade". In: Revista Iluminuras - Antropologia urbana: cidades e estilos de vida, n.4, 2001. Disponível em: http:/www.iluminuras.ufrgs.br/ documento__.html.

FIGARI, Carlos.@s outr@s carioc@s: interpelações, experiências e identidades homoeróticas no Rio de Janeiro Séculos XVII ao XX. Belo Horizonte: Editora UFMG; Rio de Janeiro: IUPERJ, 2007.

FOUCAULT, Michel. A microfísica do poder. 3 ed. Rio de Janeiro: Editora Graal, 1982.

GREEN, James N. Além do carnaval: a homossexualidade masculina no Brasil do século $X X$. São Paulo: Ed. Unesp, 2000.

GUIMARÃES, Carmem Dora. O homossexual visto por entendidos. Rio de Janeiro: Garamond, 2004.

HALBAWACHS, Maurice. A memória coletiva. São Paulo: Editora Centauro, 2004.

HANNERZ, ULF. Exploracion de la ciudad. Hacia una antropología urbana. México: Fondo de Cultura Económica, 1986.

HENNING, Carlos Eduardo. As diferenças na diferença: hierarquia e interseções de geração, gênero, classe, raça e corporalidade em bares e boates GLS de Florianópolis, SC. 2008. 144 f. Dissertação (Mestrado) - Universidade Federal de Santa Catarina, Centro de Filosofia e Ciências Humanas. Programa de Pós-Graduação em Antropologia Social, Florianópolis.

IRIART, Jorge Alberto Bernstein; CHAVES, José Carlos; ORLEANS, Roberto Ghignone de. "Culto ao corpo e uso de anabolizantes entre praticantes de musculação". In: Cad. Saúde Pública [online] v.25, n.4, 2009. p. 773-782.

KULICK, Don. Travesti: prostituição, sexo, gênero e cultura no Brasil. Tradução Cezar Gordon. Rio de Janeiro: Editora Fiocruz, 2008.

LINS DE BARROS, Myriam Moraes. "Redes sociais e cotidiano de velhos num subúrbio carioca". In: Interseções: Revista de Estudos Interdisciplinares, ano 3, n. 2. Rio de Janeiro: PPCIS-UERJ, 2001. p.233-246.

LINS DE BARROS, Myriam Moraes. "O passado no presente. Aos 70 falando do Rio de Janeiro". In: Cadernos de Antropologia e Imagem - A cidade em imagens, ano 3, n. 4. Rio de Janeiro: UERJ, 1997. p.91-119. 
LINS DE BARROS, Myriam Moraes. "Gênero, cidade e geração: perspectivas femininas". In: LINS DE BARROS, Myriam (Org). Família e Gerações. Rio de Janeiro: Editora FGV, 2006. p.17-38.

LOMNITZ, Larissa Adler. "Redes sociales y partidos políticos en Chile". In: Revista Redes. v.3, sept-nov, 2002. Disponível em: http://revista-redes.rediris.es. Acesso em 5 de agosto de 2010.

MAGNANI, José Guilherme Castor. "Quando o campo é a cidade. Fazendo Antropologia na Metrópole”. In: MAGNANI, José Guilherme C.; TORRES, Lilian de Lucca (Orgs.). $\mathrm{Na}$ Metrópole. Textos de Antropologia Urbana. São Paulo: EDUSP, 1996. p.15-53.

MAGNANI, José Guilherme Castor. Festa no Pedaço: Cultura Popular e Lazer na Cidade. São Paulo: Brasiliense, 1984.

MALUF, Sônia. "Corporalidade e desejo: Tudo sobre minha mãe e o gênero na margem”. In: Revista Estudos Feministas, v. 10, n. 1. Florianópolis: UFSC, 2002a. p. 143-153.

MALUF, Sônia. "Corpo e Corporalidade nas culturas contemporâneas: abordagens antropológicas". In: Esboços Revista do Programa de Pós-Graduação em História, v.9, n. 23. Florianópolis: UFSC, 2002b. p.87-101.

MALUF, Sônia. "O dilema de Cênis e Tirésias: corpo, pessoa e as metamorfoses de gênero". In: Fazendo Gênero III, Texto apresentado na Mesa Redonda «Corpo, sexualidade e representações». Florianópolis: UFSC, maio de 1998.

MAUSS, Marcel. "Uma categoria do espírito humano: a noção de pessoa, a noção do Eu". In: Sociologia e antropologia. São Paulo: Cosacnaify, 2003.

MAUSS, Marcel. "As Técnicas Corporais". In: Sociologia e antropologia. São Paulo: Cosacnaify, 2003.

MITCHELL, C. Social networks in urban situations. Manchester: Univ. Press, 1969.

MOTTA, Alda Britto da. "Envelhecimento e sentimento do corpo". In: MINAYO, Maria Cecília de Souza; COIMBRA JR, Carlos E. A. (Org.) Antropologia, Saúde e Envelhecimento. Rio de Janeiro: Editora Fiocruz, 2002. p.37-50.

MOTTA, Alda Britto da. "Sociabilidades possíveis: idosos e tempo geracional". In: PEIXOTO, Ehlers Clarice (Org.). In: Família e Envelhecimento. Rio de Janeiro: Editora FGV, 2004. p.109-144.

ORTNER, Sherry. "Está a Mulher para o Homem assim como a natureza para a cultura?" In: ROSALDO, Michelle; LAMPHERE, Louise. (Orgs.). A mulher, a cultura e a sociedade. Rio de Janeiro: Editora Paz e Terra, 1979. p. 95-120.

PARK, Robert E. "A cidade: sugestões para investigações do comportamento social no meio urbano". In: VELHO, O. G. (Org.). O Fenômeno Urbano. Rio de Janeiro: Zahar Editores, 1979 [1916].

PARKER, Richard. Abaixo do Equador: Culturas do desejo, homossexualidade masculina e comunidade gay no Brasil. Rio de Janeiro: Record, 2002.

PEIXOTO, Clarice. Envelhecimento e imagem: as fronteiras entre Paris e Rio de Janeiro. São Paulo: Annablume, 2000.

PELÚCIO, Larissa. "No salto: trilhas e percalços de uma etnografia entre travestis que se prostituem". In: BONETTI, Alinne; FLECHTER, Soraya (Org). Entre Saias Justas e Jogos de Cintura: gênero e etnografia na antropologia brasileira recente. Florianópolis e Santa Cruz do Sul: Editora Mulheres e EDUNISC, 2007.

PELÚCIO, Larissa. "Nos nervos, na carne, na pele: uma etnografia sobre prostituição travesti e o modelo preventivo da AIDS". Tese (Doutorado em Ciências Sociais) São Carlos: UFSCar, 2007.

PELÚCIO, Larissa. Abjeção e desejo: uma etnografia travesti sobre o modelo preventivo de AIDS. São Paulo: Annablume; FAPESP, 2009. 
PERLONGHER, Nestor. O negócio do michê: a prostituição viril em São Paulo. São Paulo: Editora Fundação Perseu Abramo, 2008.

RADCLIFFE-BROWN, A.R. Structure and Function in Primitive Society: Essays and Addresses. London: Cohen and West, 1952.

RESENDE, Claudia Barcellos. "Os limites da sociabilidade: cariocas e nordestinos na Feira de São Cristóvão”. In: Estudos Históricos, n.28. Rio de Janeiro, 2001.

RICOEUR, Paul. O si-mesmo como um outro. Campinas: Papirus, 1991.

RICOEUR, Paul. Temps et recit, Tome I. Paris : Seuil, 1983.

RICOEUR, Paul. Tempo e Narrativa. Tomo I. São Paulo: Papirus, 1994.

RICOEUR, Paul. Tempo e Narrativa. Tomo III. São Paulo: Papirus, 1997.

RICOEUR, Paul. "Memória pessoal, memória coletiva". In: RICOUER, Paul. A memória, a história, o esquecimento. Tradução de Alain François. Campinas: Editora da Unicamp, 2007. p. 106-154.

RIGAMONTE, R.C. "Severinos, Januárias e Raimundos: notas de uma pesquisa sobre os migrantes nordestinos na cidade de São Paulo". In: MAGNANI, José Guilherme; TORRES, Lílian. (Orgs.). Na metrópole: textos de antropologia urbana. São Paulo: EDUSP, 1996. p.230-252.

ROSALDO, Michelle. "O uso e o abuso da antropologia: reflexões sobre o feminismo e o entendimento intercultural”. In: Revista Horizontes Antropológicos, ano 1, n.1. Porto Alegre: PPGAS/UFRGS, 1995. p.11-36.

ROSALDO, Michelle; LAMPHERE, Louise. (Orgs.). A mulher, a cultura e a sociedade. Rio de Janeiro: Editora Paz e Terra, 1979.

SCHUTZ, Alfred. Fenomenologia e Relações Sociais. (Org.) WAGNER, Helmut R. Rio de Janeiro: Zahar Editores, 1979.

SCOTT, Joan W. "Gênero: uma categoria útil de análise histórica". In: Revista Educação e Realidade, v.16. n. 2, julho/dezembro. Porto Alegre: UFRGS, 1990. p. 522.

SILVA, Hélio R. S. Travesti: a invenção do feminino. Rio de Janeiro: RelumeDumará/Iser, 1993.

SILVA, Hélio R. S.; FLORENTINO, Cristina de Oliveira. "A sociedade dos travestis: espelhos, papéis e interpretações". In: Sexualidades brasileiras. Rio de Janeiro: RelumeDumará, 1996. p.105-118.

SIMMEL, Georg. "A Metrópole e a vida mental". In: VELHO, Otávio G. O fenômeno urbano. Rio de Janeiro: Zahar Editores, 1987.

SIMMEL, Georg. Sobre la individualidad y las formas sociales - 1 ed. Quilmes: Universidade Nacional de Quilmes, 2002.

SOARES, Luis Eduardo. "Criminalidade e violência. Rio de Janeiro, São Paulo e perspectivas internacionais", v.1, n.2. In: Comunicação e Política. Rio de Janeiro: Centro Brasileiro de Estudos Latino-Americanos - CEBELA, 1994-1995.

TERTO JR, Veriano. "Homossexuais soropositivos e soropositivos homossexuais: questões da homossexualidade masculina em tempos de AIDS". In: Sexualidades brasileiras. PARKER, Richard; BARBOSA, Regina Maria (Orgs.). Rio de Janeiro: Relume Dumará: ABIA: IMS/UERJ, 1996. p. 90-104.

VALE DE ALMEIDA, Miguel. Senhores de si. Uma interpretação antropológica da masculinidade. Lisboa: Fim de Século Edições, 2000.

VELHO, Gilberto. Individualismo e cultura: notas para uma antropologia da sociedade contemporânea. 6. ed. Rio de Janeiro: Zahar Editores, 1999a.

VELHO, Gilberto. Projeto e metamorfose: antropologia das sociedades complexas. 2.ed Rio de Janeiro: Jorge Zahar Editores, $1999 b$. 
VELHO, Gilberto (Org.). Desvio e divergência: uma critica da patologia social. 7.ed. Rio de Janeiro: Jorge Zahar Editores, 1999c. [1974]

VELHO, Gilberto. Subjetividade e sociedade: uma experiência de geração. 3. ed. Rio de Janeiro: Jorge Zahar Editores, 2002.

VENCATO, Anna Paula. Fervendo com as drags: corporalidade e perfomances de drag queens em territórios gays da Ilha de Santa Catarina. 2002. Dissertação. (Mestrado Antropologia Social) Programa de Pós-Graduação em Antropologia Social/UFSC, Florianópolis.

VENCATO, Anna Paula. "Confusões e Estereótipos: o ocultamento de diferenças na ênfase de semelhanças entre transgêneros". In: Cadernos AEL: Homossexualidade, Sociedade, Movimento e Lutas, v. 10, n.18/19. Campinas: UNICAMP / IFCH / AEL, 2003. p. 185-218.

ZALUAR, Alba. A máquina e a revolta. As organizações populares e o significado da pobreza. Rio de Janeiro: Editora Brasiliense, 1985.

ZALUAR, Alba. Da revolta ao crime S.A. $2^{\text {a }}$. ed. São Paulo: Moderna, 1996. 